\title{
Developing Senior High School Student's Chemical Literacy Skills Through Inquiry-Based Online Chemistry Learning
}

*Elly A. Zebua \& Kelly Sinaga

Pendidikan Kimia/FIP - Universitas Pelita Harapan, Tangerang - Indonesia 94119

Received 30 March 2021, Revised 26 April 2021, Accepted 28 May 2021

doi: 10.22487/j24775185.2021.v10.i2.pp126-132

\section{Abstract}

This paper is motivated by the challenges of chemistry class during the online learning period in developing students' chemical literacy skills that were found during internship two by the author at a school in North Sulawesi at Senior High School. Based on these activities, it is known that the limitations of students in understanding chemical materials and concepts during online learning pose as a challenge for teachers to carry out the chemistry lessons long distanced. This paper aims to review the development of students' literacy skills through inquiry-based learning. This paper also aims to examine the implications of chemical literacy in helping Christian teachers guide students to God's wisdom through inquiry-based chemistry's online learning. The results from this study showed that the chemical literacy skills of students in the school where the author carried out field experience program two activities showed positive results; however, it was not comprehensive. Furthermore, chemical literacy helped Christian teachers observe students' development in understanding chemical concepts and their relevance to biblical principles. This study concluded that honing chemical literacy skills through inquiry-based online learning can help students be more active in obtaining information. Good chemical literacy skills will help students make decisions based on problems that are always based on biblical principles. The author of this study suggests examining strategies in addition to inquiry-based learning, which can improve student's chemical literacy skills, especially in online chemistry learning.

Keywords: Chemical literacy, inquiry-based learning, online learning

\section{Introduction}

Education has become an important pillar that could develop generations of Indonesian to master the skills of the 21 st century to face various challenges in an increasingly advanced era. Education stakeholders realized their responsibility is not easy as Minister of Education and Culture of Indonesia, Nadiem Makarim, said that his responsibility as Minister of Education and Culture is not easy because he had to plan various strategies to increase the quality of education of Indonesia. Programme for International Students Assessment (PISA) 2018 results show that Indonesia experienced a decline compared to PISA 2015. In PISA 2015 results for the category of scientific literacy, Indonesia ranks 69 out of 76 countries with a score of 403 points (Organization for Economic Co-operation and Development, 2016). Meanwhile, Indonesia only ranks 71 out of 79 countries with a score of 396 points in PISA 2018 (Noor, 2020). Based on this data, the government has already developed various programs and strategies to enhance a better quality of education in Indonesia.

Various strategies have been carried out by the government in improving the quality of education in Indonesia, such as: carry out a major revision of the curriculum (Arnyana, 2019), increasing budget allocation to education (Utami, 2019), and also preparing future non-educational undergraduate teachers to have a high quality of competence (Pangestika \& Alfarisa, 2015). However, in the midst of the incessant government making several improvements to the quality of education, the sudden learning system had to be done online as an impact of pandemic Coronavirus Disease 2019 (COVID-19). Online learning raises new challenges in education. Kumar (2015) exposed five common problems faced by students in online learning, such as adaptability struggle, technical issues, computer literacy, time management, and self-motivation to follow the new educational trends. Furthermore, students also have difficulty understanding the teacher's explanation during online learning (Amalia \& Sa'adah, 2020). That one of the factors that cause the obstacles faced by students is due to the limitations of teachers in adapting to the online learning system. These challenges and obstacles during online learning can have an impact on reducing the quality and ability of students' chemical literacy.

Chemical literacy is basically taken from the definition of scientific literacy. Chemical literacy is

*Correspondence:

Elly A. Zebua

e-mail: zebua.ellyalbert@gmail.com

(c) 2021 the Author(s) retain the copyright of this article. This article is published under the terms of the Creative Commons Attribution License 4.0, which permits unrestricted non-commercial use, distribution, and reproduction in any medium, provided the original work is properly cited. 
the ability of students to identify, cultivate, analyze, solve problems relevant to real life, understand and explain the surrounding scientific phenomena (Perkasa \& Aznam, 2016). Based on the second online field experience program (Program Pengalaman Lapangan/PPL) for approximately six weeks at a school in North Sulawesi, found that implementation of inquiry-based learning to improve student's chemical literacy can be one solution to overcome various challenges or obstacles, especially to avoid a decline in the quality of student learning. Inquiry-based learning (IBL) models are student-centered learning (Bilgin, 2009). The researcher found that the online learning system supports teachers to implement IBL that requires students to take an active role during online learning in order to stimulate the development of student chemical literacy. IBL could help Christian teachers in carrying out Christcentered, teacher-directed, and student-oriented learning. So, developing students' chemical literacy through IBL can help teachers ensure that each student understands the chemistry learning material that has been studied and is able to analyze chemical phenomena and explain them scientifically.

Depart from all exposures to the challenges of education in facing the demands of $21^{\text {st }}$ century skills, the formulation of the problem of this research are 1) Why is chemical literacy important for students learning activities? 2) How to implement IBL models to improve student's chemical literacy? And 3) What are the implications of implementing IBL during online learning in the pursuit of developing student's chemical literacy for Christian learning practices? This paper aims to review the development of student's literacy skills through inquiry-based learning. This paper also aims to examine the implications of chemical literacy in helping Christian teachers guide students to God's wisdom through inquiry-based chemistry's online learning (Knight, 2009). Christian teachers need to guide students to think about what God thinks about science (Poythress, 2006). This is in line with the Christian teacher's task, which is not only focused on the presentation of the material but through that material, the students are also led to knowledge and obey God (Brummelen, 2009).

\section{Methods}

This research was conducted in a Senior High School in North Sulawesi. The research subjects were all students of grade XII Science, totaling 30 students. The method used in this research is a qualitative descriptive method, through the triangulation of data from the author's portfolio during an online field experience program. This survey was conducted for six weeks. Efforts to develop high school students' chemical literacy skills are made in stages, as in Figure 1.

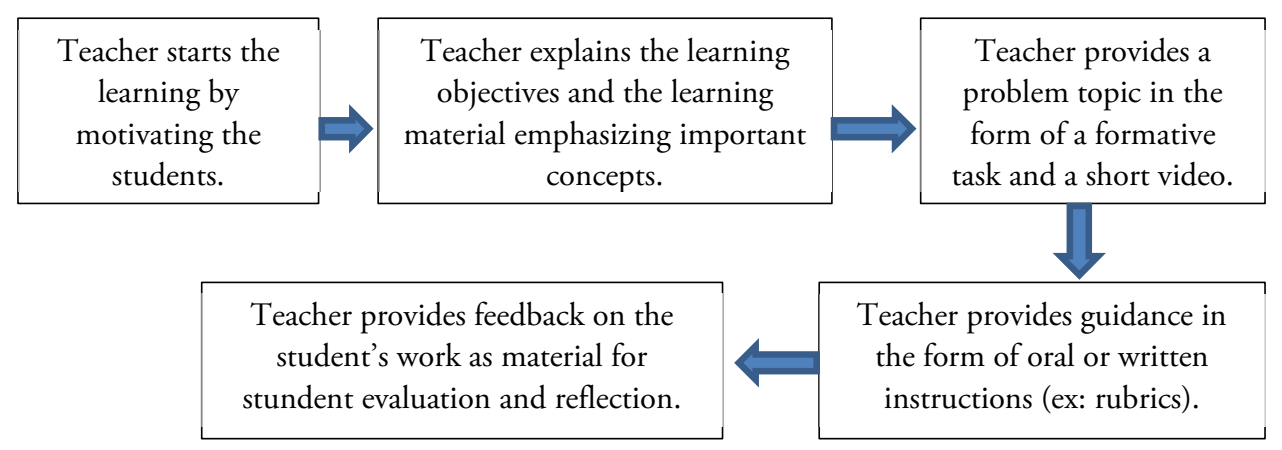

Figure 1. Implementation of IBL models's diagram

\section{Results and Discussion}

Chemical literacy is one of the important skills to develop for students in order to master $21^{\text {st }}$ century skills. These $21^{\text {st }}$ century skills are more important to students now than ever before. They not only provide a framework for successful learning in the classroom but ensure students can thrive in a world where change is contestant and learning never stops. Some of the $21^{\text {st }}$ skill such as: critical thinking skills, communication skills, creativity and innovation skills, and collaboration skills. If it is related to that $21^{\text {st }}$ century skills, chemical literacy skill is more about critical thinking skills. Good chemical literacy skills will help students improve their critical thinking skills and have an impact on the development's student's metacognitive skills, which allows students to reflect, monitor any information about the knowledge they gain, or process and evaluate all decisions made so that students are truly prepared to face the progress of the $21^{\text {st }}$ century. This reason encourages the author to engage in the development of the student's literacy in chemistry through class XII science teaching materials, in which, in this class, students are trained to be able to understand chemical concepts and to analyze scientifically various phenomena of a colligative nature of solutions that exist in everyday life.

However, as explained in the preface above, the covid-19 pandemic has brought about several changes in the educational system, such as the 
implementation of online learning activities. The online learning system offers a number of challenges and obstacles in learning activities which, in turn, can have an impact on the decline in students' chemical literacy skills. Faced with this problem, the authors try to apply a learning model that is relevant to the conditions of online learning and that supports the development of students' chemical literacy skills through inquiry-based learning models.

IBL models are student-oriented learning (Bilgin, 2009). IBL encourages students to ask questions, find ideas that are relevant to the problem, and train students' ability to think critically (Duran \& Dökme, 2016). This is in line with the objective of the IBL models, which is to give students experience in identifying real-life problems, reasoning, and discussion, and to draw conclusions/solutions to overcome these problems (Imansari et al., 2018). The inquiry-based learning model invites students to investigate various sources of credible information in order to stimulate students' scientific literacy skills in locating problems, correct reasoning about problems, and finding the right solutions (Anggraeni et al., 2020). The inquiry-based learning models also really help teachers improve students' chemical literacy skills because the inquiry-based learning models use a student-oriented learning approach (Nawangati \& Dwiningsih, 2017).

In addition to IBL models that can facilitate students in developing students' chemical literacy skills, IBL models is also relevant to the current online learning system. Online learning systems tend to be student-oriented, so students need to have an independent attitude in learning (Sadikin \& Hamidah, 2020). The online learning system also encourages students not to depend on the teacher for information, but to build their own understanding of the material being studied (Syarifudin, 2020). Syarifudin also said that the online learning system would help students not only memorize but understand the concept of the learning material.

The teacher can implement IBL models by giving students the opportunity to solve a problem, finding facts, concepts, and chemical principles that are coherent in solving the problem (Lailihuda \& Ismono, 2019). Asni et al. (2020) provide five steps in the implementation of IBL. The five steps in question are orientation, problem formulation, hypothesis formulation, data collection, and drawing conclusions (Asni et al., 2020). In line with this, IBL models can also be implemented by presenting material explanations, providing problems for students, formulating hypotheses, collecting data, and drawing conclusions. (Aini \& Yonata, 2020). The teacher can also implement the inquiry-based learning model by adding experimental activities carried out by the students to obtain data according to the hypotheses that have been developed by them. (Mardika, 2020). The implementation of IBL models can also be applied by providing opportunities for students to evaluate and reflect on the work process and the conclusions they have obtained (Kristianto, 2019).

During the online field experience program 2, the results obtained are that the implementation of IBL through online chemistry learning can help teachers create learning activities that encourage student's role more active in learning. The effective performance of students in expanding their knowledge of chemistry stimulates the development of their chemical literacy skills. In addition to stimulating the development of students' chemical literacy skills, implementation IBL models during field experience programs could enable students to overcome various obstacles, such as unstable networks, so that online chemistry learning can continue effectively.

As previously described, this article seeks to stimulate the development of students' chemical literacy skills in terms of knowledge and competence through IBL models. This helps teachers create an assessment for students that are adapted to the two indicators of literacy aspects, such as making videos and also working on questions of formative assessment that are relevant to measuring students' chemical literacy skills. In addition, here the author tries to give two examples of questions that were given to students during online field experience program 2 in the formative assessment of class XII Science:

a. Questions number 3 of 8 questions:

In a country that has four seasons, the temperature when it is cold can reach $-5.35^{\circ}$ C. However, even in these climatic conditions, seawater is still in a liquid state. Why? Explain the results of your analysis of this phenomenon!

b. Question number 7 of 8 questions:

Here is a picture of the urea solution diagram. The boiling point of a urea solution is indicated in Figure 2.

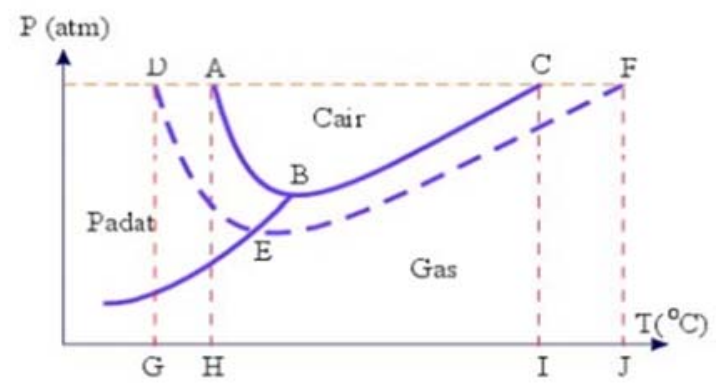

Figure 2. P-T phase diagram of water and urea solution 
The questions in section an above are examples of questions designed to measure students' chemical literacy in the competency aspect. This question is a question that is based on real-life, and students are asked to be able to scientifically analyze this phenomenon from the chemical concept of the colligative nature of the material studied. The results obtained were that some students could find a link from this event to the colligative nature of the solution, namely a decrease in the freezing point. However, there is still an inaccurate concept of student analysis. In fact, some students honestly wrote that they couldn't find a correlation between the concept of colligative properties of solutions that had been studied and examples of related chemical phenomena that occurred in real life but still tried to provide an explanation. From this, the author can conclude that questions like this can stimulate students to think and find a correlation between the chemical concepts they have learned and the existing chemical phenomena. Of course, this also has an impact on stimulating the development of students' chemical literacy skills, especially in the aspect of competence.

Question part b is an example of a question designed to measure chemical literacy skills based on knowledge aspects indicators. The results obtained are shown in the following Figure 3.

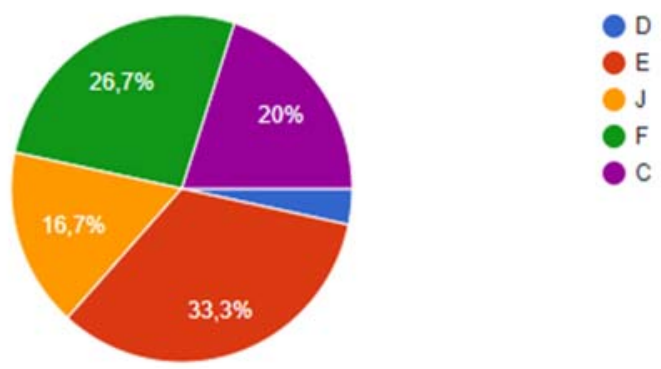

Figure 3. Percentage of student responses

Based on the Figure 3, it can be concluded that only $16.7 \%$ of students answered correctly. From this, the author can conclude that the majority of students in class XII IPA still do not understand how to read a P-T diagram of water and solution as in question number 7 .

In addition to giving formative assessment, the author also asks students to make short videos that aim to measure students' chemical literacy skills in aspects of knowledge and competence. In developing students' chemical literacy based on indicators on the aspect of knowledge, students are asked to insert an example question that is relevant to the topic of the student's experiment and to conduct a discussion on the issue. Meanwhile, for the competence aspect, students are invited to do a small experiment that applies the chemical concept of the colligative nature of the solution in the experiment. Besides, students were also asked to find the relevance of the experimental results obtained from a Christian perspective. The results obtained indicate a stimulus for the development of student literacy in chemistry, which can be seen in Table 1. Striving to develop students' chemical literacy skills through IBL models also helps Christian teachers build a student-oriented learning classroom and make God the center of learning. The existence of God-centered learning will help Christian students hone all skills relevant to the $21^{\text {st }}$ century for the glory of God. God-centered learning helps Christian education not to fall into wrong learning practices or educational philosophies that do not conform to biblical principles, such as the philosophy of humanism. The philosophy of humanism places humans as the ultimate reality, and this can hold students in learning that is centered on themselves and not on God.

As stated at the beginning, the effort to develop students' chemical literacy through IBL can develop students' critical thinking skills. Good critical thinking and chemical literacy skills can help Christian students to think of any information they have obtained and to identify whether the information has values that are in line with God's truth. This helps the Christian students to have the right perspective on his life and have a way of thinking that always reflects God's way of thinking (Berkhof \& Til, 2004), who is able to analyze all phenomena related to chemistry/science as a real way to serve God through His creation (Greene, 1998). 
Table 1. The stimulus for the development of student's chemical literacy skill

\begin{tabular}{ccc}
\hline \multirow{2}{*}{ Indicator } & Criteria & Development of student's chemical literacy skills \\
\cline { 3 - 3 } & Before & After \\
\hline
\end{tabular}

Students still vaguely understand each concept, formula, and the

Aspect of Knowledg

e

understand the concept

of science, the

reasoning process and

prove an idea relationship between each

chemical concept in the colligative nature of the solution matter.
Students are able to analyze chemical concepts through an example problem related to students' analysis videos and their solutions.

$\begin{array}{ll}\text { Aspect of } & \begin{array}{l}\text { able to explain } \\ \text { phenomena } \\ \text { scientifically, evaluate, } \\ \text { predict and prove in a } \\ \text { ce }\end{array}\end{array}$

able to explain scientifically, evaluate, predict and
Students listen to every phenomenon of the colligative nature of the solution through the teacher's explanation only.

\begin{abstract}
Students are able to independently find an example of the phenomenon of the collective nature of a solution and perform experiments, analyzes, and draws conclusions about these phenomena that are related to the concept of chemistry in an appropriate way.
\end{abstract}

By improving students' chemical literacy skills, teachers must also be able to understand chemistry while still depending on God's truth and do not see the concept of chemistry as contradicting the truth but are guided to know more about God and His truth (Poythress, 2006).

However, the authors also recognize the writer's limitations in implementing IBL models during online chemistry learning at a Christian school in North Sulawesi at the Senior High School. One of them is that the author still lacks to emphasize important concepts of the subject of chemistry taught to the students at the beginning of each learning activity. In addition, the authors also admit that they have not yet fully implemented all the platforms used for learning chemistry online. This is the first time that the author's experienced online learning activities. The author's limited experience and competence can be a factor that hinders the effective implementation of chemistry learning. Thus, through this online field experience program 2, the author realizes that, in preparing the young generation of Indonesia who is qualified in the $21^{\text {st }}$ century, teachers who are competent in pedagogy and master the technology-based learning media are very necessary. The competence and quality of good teachers, will greatly help students to understand the concepts of chemistry, develop chemical literacy skills and be able to think critically in the face of the rapid development of the $21^{\text {st }}$ century.

\section{Conclusions}

Based on all the explanations above, it can be concluded that efforts to develop students' chemical literacy skills are very important in building effective learning for students. The development of students' chemical literacy helps students to take a more active role in obtaining knowledge of the material being studied. The development of chemical literacy is also very appropriate to be pursued through IBL models, IBL models strongly support studentoriented learning systems and also help the Christian teacher to fulfill his role as a student's guide and facilitator to the wisdom of God's truth through student-centered and Christ-centered learning.

The author concludes that the student's chemical literacy skills in the school where the author completed online field experience program two are categorized as very good, although not comprehensive. Furthermore, The author also realizes that it is very important for teachers, especially Christian teachers who teach chemistry, to first improve their chemistry skills and understand their identity as a Christian teacher who is responsible for guiding students to the wisdom of God through chemistry. The hope is that each student will be able to admire Allah and obey Allah through the chemistry they have learned.

\section{Acknowledgments}

The author would like to thank Mrs. Kelly Sinaga, who has always guided the author. The author also thanks Alvin S. P. Zebua, Clement Foo, Juwita Gea, and Junnivia Thio, who have always facilitated, supported, and motivated the author during the process of completing this writing.

\section{References}

Aini, N., \& Yonata, B. (2020). Implementasi model pembelajaran inkuiri terbimbing pada materi 
kesetimbangan kimia untuk melatihkan keterampilan berpikir tingkat tinggi. Unesa Journal of Chemical Education, 9(2), 238-244.

Amalia, A., \& Sa'adah, N. (2020). Dampak pandemi covid-19 terhadap kegiatan belajar mengajar di Indonesia. Jurnal Psikologi, 13(2), 214-225.

Anggraeni, A. Y., Wardani, S., \& Hidayah, A. N. (2020). Profil peningkatan kemampuan literasi kimia siswa melalui pembelajaran inkuiri terbimbing berbasis kontekstual. Jurnal Inovasi Pendidikan Kimia, 14(1), 2512-2523.

Arnyana, I. B. (2019). Pembelajaran untuk meningkatkan kompetensi 4C (communication, collaboration, critical thinking dan creative thinking) untuk menyongsong era abad 21, Prosiding: Konferensi Nasional Matematika dan IPA Universitas PGRI Banyuwangi, (pp. 1-13). Banyuwangi: Universitas PGRI Banyuwangi.

Asni., Wildan., \& Hadisaputra, S. (2020). Pengaruh model pembelajaran inkuiri terbimbing terhadap hasil belajar kimia siswa materi pokok hidrokarbon pada kelas XI PMIPA SMA N 1 WOHA tahun ajaran 2019/2020. Chemistry Education Practice, 3(1), 17-22.

Berkhof, L., \& Til, C. V. (2004). Dasar pendidikan Kristen (Tim Penerjemah, Trans.). Surabaya: Momentum. (Original work published 1990).

Bilgin, I. (2009). The effects of guided inquiry instruction incorporating a cooperative learning approach on university students' achievement of acid and bases concepts and attitude toward guided inquiry instruction. Scientific Research and Essay, 4(10), 1038-1046.

Brummelen, H. V. (2009). Berjalan dengan Tuhan di dalam kelas. Tangerang: Universitas Pelita Harapan Press.

Duran, M., \& Dökme, I. (2016). The effect of the inquiry-based learning approach on students' critical thinking skills. Eurasia Journal of Mathematics, Science \& Technology Education, 12(12), 2887-2908.

Greene, A. E. (1998). Reclaiming the future of christian education: A transforming vision. Colorado Springs: Association of Christian Schools International.

Imansari, M., Sudarmin., \& Sumarni, W. (2018). Analisis literasi kimia peserta didik melalui pembelajaran inkuiri terbimbing bermuatan etnosains. Jurnal Inovasi Pendidikan Kimia, 12(2), 2201-2211.

Knight, G. R. (2009). Filsafat \& pendidikan: Sebuah pendahuluan dari perspektif Kristen. Jakarta: Universitas Pelita Harapan Press.
Kristianto, Y. (2019). Penerapan model pembelajaran inkuiri untuk meningkatkan berpikir kritis dan hasil belajar siswa dalam pembelajaran IPA kelas IV SD. Jurnal Mitra Pendidikan (JMP Online), 3(11), 1428-1443.

Kumar, S. (2015). 5 common problems faced by students in e-learning and how to overcome them. Retrieved July 10, 2019, from https://elearningindustry.com/5-commonproblems-faced-by-students-in-elearningovercome.

Lailihuda, S. M., \& Ismono. (2019). Penerapan model pembelajaran inkuiri terbimbing untuk melatihkan keterampilan proses sains siswa pada materi kesetimbangan kimia. Unesa Journal of Chemical Education, 8(2), 275-281.

Mardika, I. K. (2020). Upaya meningkatkan sikap ilmiah dan hasil belajar kimia melalui penerapan model pembelajaran inkuiri. Indonesian Journal of Educational Development, 1(2), 311-321.

Nawangati, A. Z. I., \& Dwiningsih, K. (2017). Pengembangan lembar kegiatan siswa (LKS) berorientasi inkuiri terbimbing untuk melatihkan kemampuan literasi sains pada materi kesetimbangan kimia. UNESA Journal of Chemical Education, 6(2), 334-338.

Noor, F. M. (2020). Memperkenalkan literasi sains kepada peserta didik: Perspektif calon guru PAUD. ThufuLA: Jurnal Inovasi Pendidikan Guru Raudhatul Athfal, 8(1), 56-67.

Organization for Economic Co-operation and Development (OECD). (2016). PISA 2015 results (volume I): Excellence and equity in education. Paris: OECD Publishing.

Pangestika, R. R., \& Alfarisa, F. (2015). Pendidikan profesi guru (PPG): Strategi pengembangan profesionalitas guru dan peningkatan mutu pendidikan Indonesia, Prosiding Seminar Nasional Pendidikan Ekonomi FE UNY (pp. 671-683). Yogyakarta: Pascasarjana Universitas Negeri Yogyakarta.

Perkasa, M., \& Aznam, N. (2016). Pengembangan SSP kimia berbasis pendidikan berkelanjutan untuk meningkatkan literasi kimia dan kesadaran terhadap lingkungan. Jurnal Inovasi Pendidikan IPA, 2(1), 46-57.

Poythress, V. S. (2006). Redeeming science: A Godcentered approach. Wheaton: Crossway Books.

Sadikin, A., \& Hamidah, A. (2020). Pembelajaran daring di tengah wabah covid-19 (Online learning in the middle of the covid-19 pandemic). BIODIK: Jurnal Ilmiah Pendidikan Biologi, 6(2), 214-224.

Syarifudin, A. S. (2020). Implementasi pembelajaran daring untuk meningkatkan 
mutu pendidikan sebagai dampak diterapkannya social distancing. Metalingua: Jurnal Pendidikan Bahasa dan Sastra Indonesia, 5(1), 31-34.
Utami, S. (2019). Meningkatkan mutu pendidikan Indonesia melalui peningkatan kualitas personal, profesional, dan strategi rekrutmen guru, Prosiding Seminar Nasional Pendidikan FKIP (pp. 518-527). Serang: Universitas Sultan Ageng Tirtayasa. 